Застело Ольга В'ячеславівна

старший викладач кафедри іншомовної підготовки відомчий ВН3, м. Київ, Україна

girzov@ukr.net

\title{
ІНТЕГРОВАНИЙ ПІДХІД ДО ОЦНЮЮВАННЯ РІВНЯ СФОРМОВАНОСТІ ІНШОМОВНОЇ КОМУНІКАТИВНОЇ КОМПЕТЕНТНОСТІ ЗА ДОПОМОГОЮ ШТУЧНИХ НЕЙРОННИХ МЕРЕЖ
}

\begin{abstract}
Анотація. У статті розглядається метод визначення інтегральної оцінки рівня сформованості іншомовної комунікативної компетентності слухачів групою експертів у процесі комплексного тестування з іноземної мови. Використання математичних методів і сучасних спеціалізованих програмних засобів під час проведення комплексного тестування слухачів, значно вдосконалюють експертні методи, зокрема у напрямку підвищення ступеня достовірності оцінювання. Залучення можливостей програмного аналітичного середовища, що реалізує моделювання нелінійного узагальнення на основі штучних нейронних мереж, підвищують точність оцінювання і дозволяють у подальшому ефективно використовувати накопичений у моделі досвід компетентних експертів.
\end{abstract}

Ключові слова: експертне оцінювання; медіана Кемені; коефіцієнт конкордації; штучна нейронна мережа.

\section{1. ВСТУП}

Постановка проблеми. Питання покращення якості тестування з іноземних мов, а, отже, і підвищення надійності отриманих результатів оцінювання рівня сформованості іншомовної комунікативної компетентності (ІКК) слухачів безпосередньо впливає на вдосконалення процесу навчання іноземних мов.

Експертні методи, що застосовуються під час проведення комплексного тестування слухачів з іноземної мови, постійно вдосконалюються, зокрема завдяки все зростаючому використанню математичних методів і спеціалізованих програмних засобів. У будь-якому випадку експертне оцінювання рівня сформованості IКК слухачів - це процес вимірювання або процедура порівняння рівня сформованості ІКК слухачів за обраними покажчиками/ознаками (результатами комплексного тестування). 3 огляду на проблему, яка досліджується, найбільший інтерес становлять два етапи: отримання експертних оцінок й оброблення отриманих даних.

Математично-статистичні методи оброблення експертних оцінок необхідно застосовувати в усіх випадках, коли вихідні дані $\epsilon$ результатами роботи експертних комісій, i потрібно знайти обгрунтовану узгоджену думку групи експертів для представлення заключних результатів з високим ступенем достовірності.

Наразі інтуїтивно прийнятною $є$ вимога стабільності на певному інтервалі часу сформованої авторитетними експертами цільової функції оброблення результатів комплексного тестування, яка у більшості випадків матимете нелінійний характер.

Аналіз останніх досліджень і публікацій. Питання теорії і практики, пов'язані 3 типовими стадіями експертного оцінювання, а саме 3 методами оцінювання узгодженості інформації від групи експертів, а також з моделюванням процесу іiі оброблення висвітлено в працях багатьох дослідників, зокрема С. Д. Бєшелєва [1], О. І. Орлова [6], С. П. Хабарова [8].

Над теоретичними аспектами сучасних технологій збору даних i аналізу структурованої інформації (Data Mining) і їх практичним застосуванням працювали такі 
зарубіжні й вітчизняні фахівці як Дж. Гінтон [10], П. Ройяс [11], П. Д. Васерман [12], Д. К. Монтгомері [5], $\quad$ В. М. Лазарєв, О. П. Свиридов [4], Л. Н. Ясницкий [9], І. П. Гайдишев [2], М. Б. Паклін, В. І. Орєшков [7] та інші.

Проте інтегроване застосування деяких математично-статистичних методів 3 їх програмними реалізаціями для оброблення групових експертних оцінок рівня сформованості ІКК слухачів за результатами комплексного тестування ще недостатньо досліджено.

Метою цієї статті є обгрунтувати інтегрований підхід оброблення інформації під час експертного оцінювання рівня сформованості ІКК слухачів за результатами комплексного тестування, що передбачає підвищення достовірності групової оцінки і точності функції оцінювання на основі застосування методу медіани Кемені і штучних нейронних мереж.

Для досягнення цієї мети слід оцінити надійність і переваги запропонованого інтегрованого підходу, що реалізує зазначені методи за допомогою сучасних інформаційних технологій.

\section{2. РЕЗУЛЬТАТИ ДОСЛІДЖЕННЯ}

Ефективність використання результатів експертного оцінювання рівня сформованості ІКК слухачів за результатами комплексного тестування цілковито визначається формуванням групи експертів (членів екзаменаційної комісії) 3 метою отримання від них об'єктивних оцінок і залежить від застосовуваної методики їх подальшого оброблення з метою отримання інтегральної оцінки рівня сформованості ІКК слухачів.

У більшості випадків екзаменаційні комісії під час приймання екзамену з іноземної мови складаються 3 3-5 членів (експертів). Кожний 3 експертів оцінює рівень сформованості ІКК за певним аспектом і виставляє свою оцінку (бал). Виникає необхідність у попередньому обробленні отриманої від експертів інформації. Задля цього можливо використати підхід, коли слушно застосовувати метод медіани Кемені разом 3 обчисленням коефіцієнта конкордації групи експертів, що дозволить зменшити розмірність вектора вхідних даних до прийнятної величини для подальшого оброблення.

Наступним важливим завданням для формування інтегральної оцінки $\epsilon$ оброблення індивідуальних оцінок слухачів, отриманих за кожний аспект ІКК (за окремий тест). Переважна кількість прикладних задач обчислення комплексного результату, які розв'язуються методом математичного моделювання, зводяться до знаходження певної складної функції, яка здійснює багатовимірне перетворення вектора вхідних параметрів у вектор вихідних параметрів. Універсальним інструментом побудови цієї функції є нейромережеві технології.

Загальна ідея інтегрованого підходу до оцінювання рівня сформованості IКК слухачів за результатами комплексного тестування з використанням методу медіани Кемені і штучних нейронних мереж представлена на рис. 1.

Слухачі під час комплексного тестування (декілька тестів) демонструють свій рівень ІКК, що оцінюється групою експертів (екзаменаторами) з виставленням кожним 3 них оцінки за певною шкалою вимірювання. Використовуючи можливості програмної надбудови AtteStat, на основі матриць результатів для кожного 3 тестів обчислюється коефіцієнт конкордації даної групи експертів і за його значенням робиться висновок щодо узгодженості їхніх оцінок. У разі необхідності приймаються рішення щодо проведення коректування складу групи. Також матриці результатів використовуються як вхідні дані для визначення за допомогою метода медіани Кемені експерта зі складу групи, оцінки якого будуть вважатися остаточними за відповідний тест. 


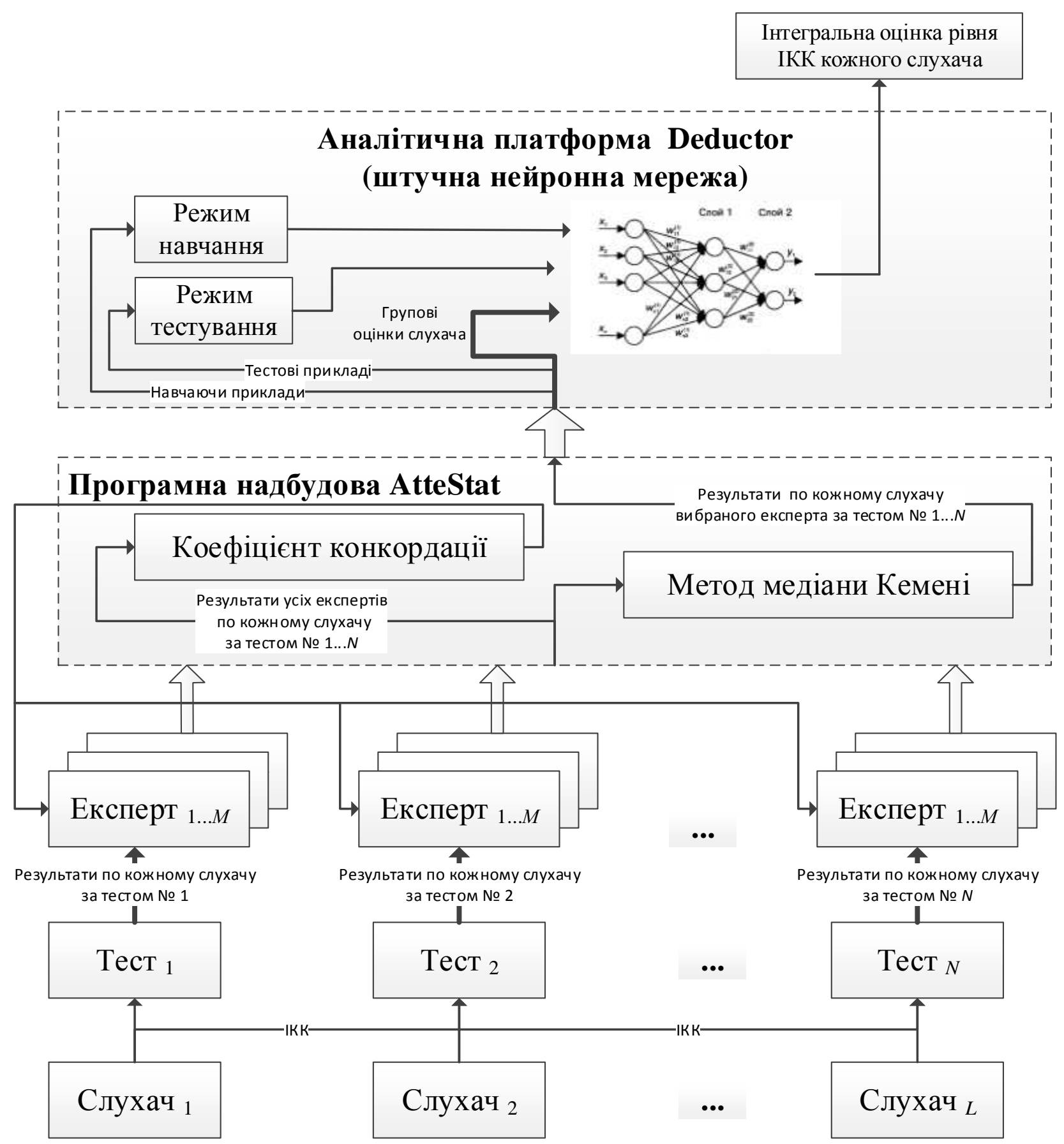

Рис. 1. Структура інтегрованого підходу оцінювання рівня сформованості IКК за результатами комплексного тестування

Вихідний масив оцінок цього етапу оброблення подається на вхід моделі, реалізованої за допомогою штучної нейромережевої технології у середовище Deductor Studio Academic. 3 цією моделлю завчасно проводилось навчання і тестування на основі репрезентативних вибірок еталонних прикладів результатів комплексного тестування з іноземної мови, які надавались авторитетними експертами. Це дозволяє говорити про достатньо об' єктивну процедуру формування інтегрованої оцінки рівня 
сформованості ІКК слухача, яка може бути задіяна во міру необхідності протягом тривалого періоду часу.

Розглянемо стисло основні аспекти щодо використання спеціалізованих програмних продуктів AtteStat i Deductor Studio Academic для розв'язання завдань запропонованого інтегрованого підходу.

Програма аналізу даних AtteStat призначена для професійного статистичного оброблення даних і виконана у вигляді надбудови до електронних таблиць Microsoft Excel під управлінням OC Microsoft Windows.

У програмному забезпеченні застосовуються різні методи оброблення експертних оцінок, з поміж яких задіяно метод отримання колективної думки - медіана Кемені, та метод дослідження узгодженості думок експертів - коефіцієнт конкордації. Методи, які застосовують у цьому програмному забезпеченні, розраховані на оброблення вихідної матриці певної структури.

Медіана Кемені - це вибір узгодженої думки експертів, коли матриця опитування експертів $є$ ранжируваннями. Нехай матриця опитування має розміри $n$ рядків на $m$ стовпців, де $n$ - кількість об'єктів, $m$ - кількість експертів. Запишемо задану множину ранжирувань у вигляді $\left\{P_{1}, P_{2}, \mathrm{~K}, P_{n}\right\}$. Нехай $d\left(P, P_{i}\right)$ - відстань між довільним ранжируванням $P$ і ранжируванням $P_{i}, i=1,2, \ldots, m$. Тоді ранжирування $P$, що належить до ир

$$
M\left\{P_{1}, P_{2}, \mathrm{~K}, P_{m}\right\}=\arg \min _{P} \sum_{i=1}^{m} d\left(P, P_{i}\right)
$$

називається медіаною Кемені.

Відстань між ранжируваннями $k$ и $l$ визначається за такою формулою:

$$
d\left(P_{k}, P_{l}\right)=\sum_{i=1}^{n} \sum_{j=1}^{n}\left|p_{i j}^{(k)}-p_{i j}^{(l)}\right|
$$

де $p_{i j}^{()}, i=1,2, \mathrm{~K}, n, j=1,2, \mathrm{~K}, n$ - елементи матриць відносин часткового порядку ранжирувань $k$ и $l$, відповідно, які автоматично обчислюються програмою на підставі матриці опитування експертів.

За визначенням медіана Кемені знаходиться лише серед ранжирувань, заданих матрицею опитування, що аналізується. Отже. розв'язанням буде ранжирування, зроблене одним з експертів, наразі програма додатково вказує номер цього експерта.

Приклад результатів обчислення експертних оцінок за медіаною Кемені для матриці опитування експертів (табл. 1) наведено на рис. 2.

Таблиия 1

\section{Матриця опитування експертів}

\begin{tabular}{|l|c|c|c|c|c|}
\hline & Експерт_1 & Експерт_2 & Експерт_3 & Експерт_4 & Експерт_5 \\
\hline Tест_1 & 4 & 3 & 3 & 3 & 4 \\
\hline Tест_2 & 5 & 5 & 5 & 4 & 3 \\
\hline Tест_3 & 4 & 5 & 4 & 5 & 4 \\
\hline
\end{tabular}




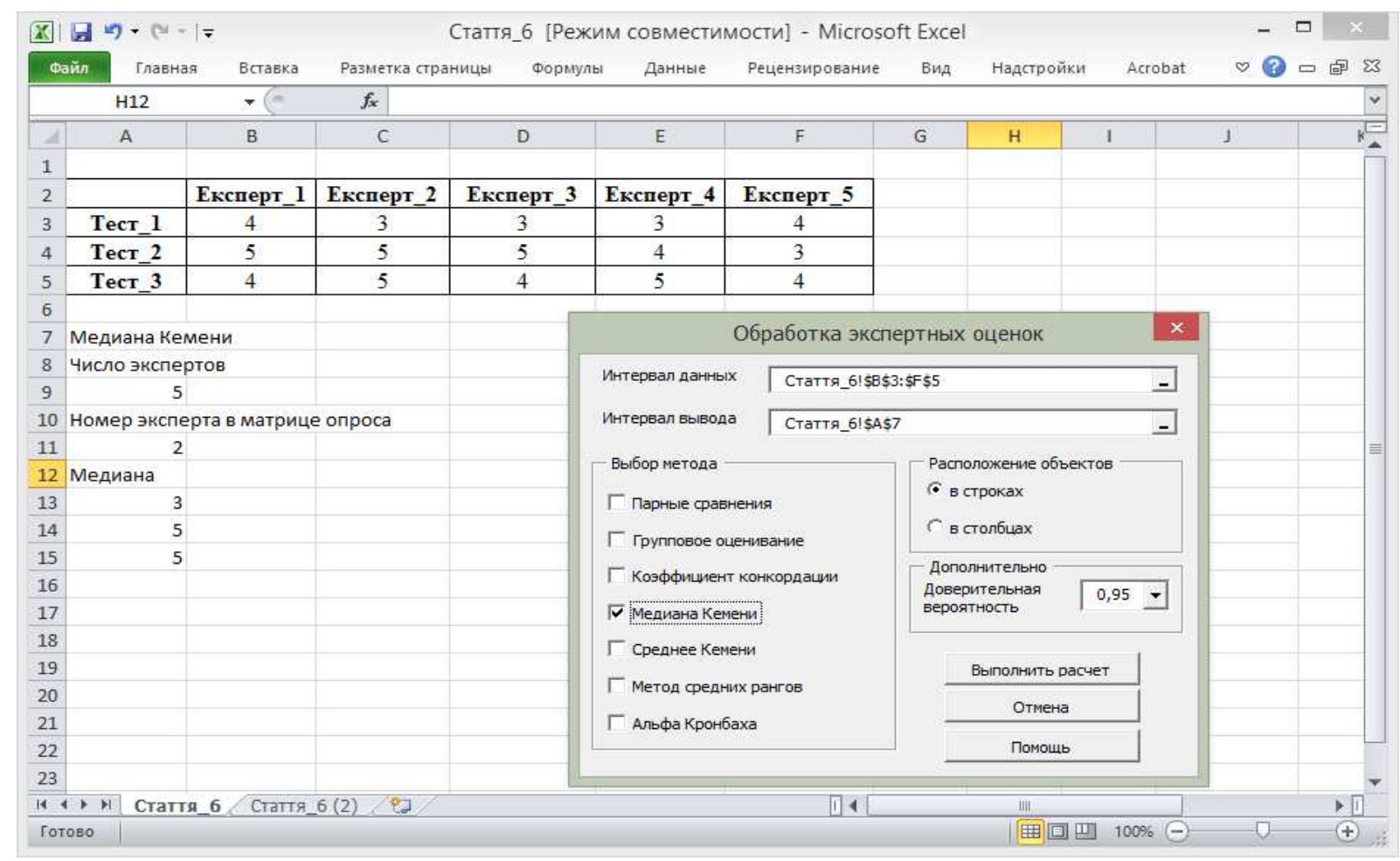

Pис. 2. Екранне вікно програми «AtteStat» результатів обчислення експертних оцінок за медіаною Кемені

Обчислення коефіцієнта конкордації Кендала, призначеного для дослідження, чи добре узгоджуються один 3 одним представлені експертами ранжирування, здійснюється за такою формулою:

$$
W=\frac{\sum_{i=1}^{n}\left(\sum_{j=1}^{k} x_{i j}-\frac{k(n+1)}{2}\right)^{2}}{\frac{1}{12} k^{2} n\left(n^{2}-1\right)-k \sum_{j=1}^{k} B_{j}},
$$

де $x_{i j}, i=1,2, \ldots, n ; j=1,2, \ldots, k$ - масив рангових оцінок, $n$ - число тестів, $k$ - число експертів, $B_{j}, j=1,2, \ldots, k$ - поправки на об'єднані ранги в оцінках експертів, що обчислюються за такою формулою:

$$
B=\frac{1}{12} \sum_{i=1}^{n} n_{i}\left(n_{i}^{2}-1\right)
$$

де $m$ - кількість груп об'єднаних рангів у цьому експертному оцінюванні, $n_{i}, i=1,2, \ldots, k$ - кількість рангів в $i$-й групі.

Величина обчисленого програмою $W$-значення більше 0,7-0,8 означає, що надані експертами ранжирування добре узгоджені. У протилежному випадку можна припустити, що ранжирування неоднорідні. Тоді рекомендується застосувати методи кластерного аналізу з використанням відповідної міри відмінності для визначення узгоджених груп експертів. рис. 3.

Приклад результатів обчислення програмою коефіцієнта конкордації наведено на 


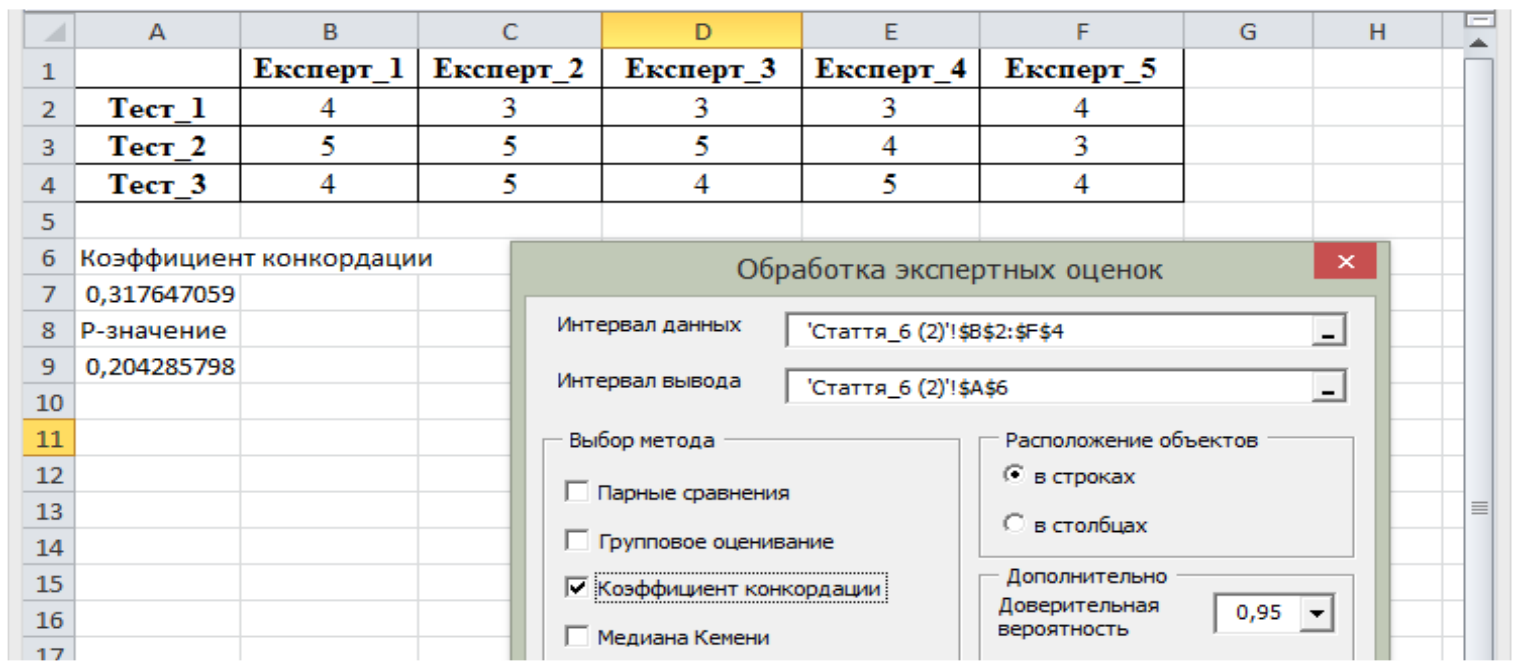

Pис. 3. Екранне вікно програми «AtteStat» з результатами обчислення коефіиієнта конкордації

Процес оброблення результатів тестування 3 іноземної мови пов'язаний 3 розумовою діяльністю експертів, які входять до складу екзаменаційної комісії. На сучасному етапі розвитку інформаційних технологій задля коректного обчислення результатів тестування необхідно використовувати обчислювальну систему, в основу якої було би покладено той самий принцип оброблення даних, що відбувається у мозку людини. Тому розглянемо підхід, що грунтується на машинному навчанні, - штучні нейронні мережі (ШНМ). Особливо прийнятним $є$ те, що вони можуть моделювати практично будь-які залежності, зокрема нелінійні.

Завдяки абстрагуванню ШНМ створює образ, формально відображений низкою ознак, якими в досліджуваному завданні є результати, отримані під час виконання слухачами окремих тестів (рис. 4). На виході система повинна сформувати значення, що вказує на рівень сформованості ІКК слухача, що однозначно визначає комплексну оцінку за результатами всіх тестів.

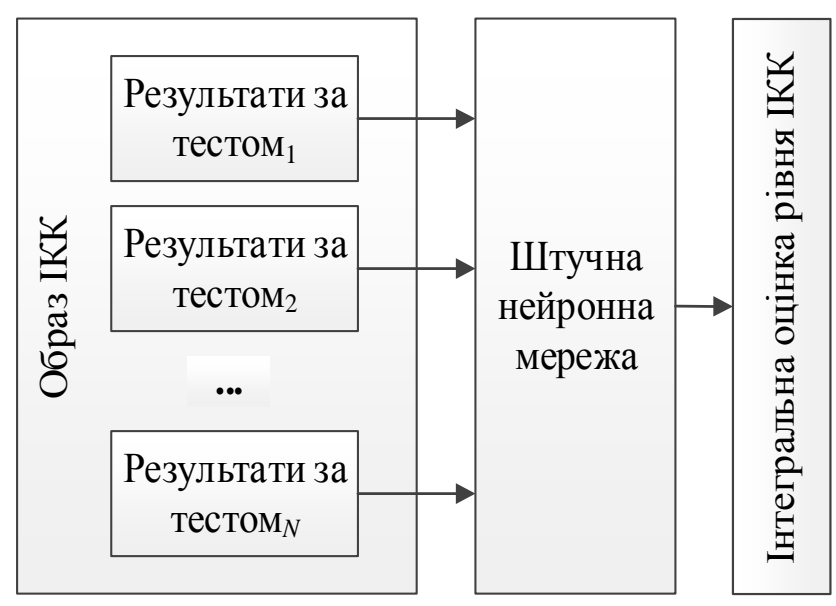

Рис. 4. Визначення рівня сформованості IКК за низкою ознак

Штучна нейронна мережа $\epsilon$ паралельно-розподіленою системою процесорних елементів нейронів, (рис. 5), які здатні виконувати найпростіше оброблення даних. Ця система здатна налаштовувати власні параметри під час навчання на емпіричних даних. Накопичені знання нейронної мережі зосереджені у вагах міжелементних зв’ язків. 


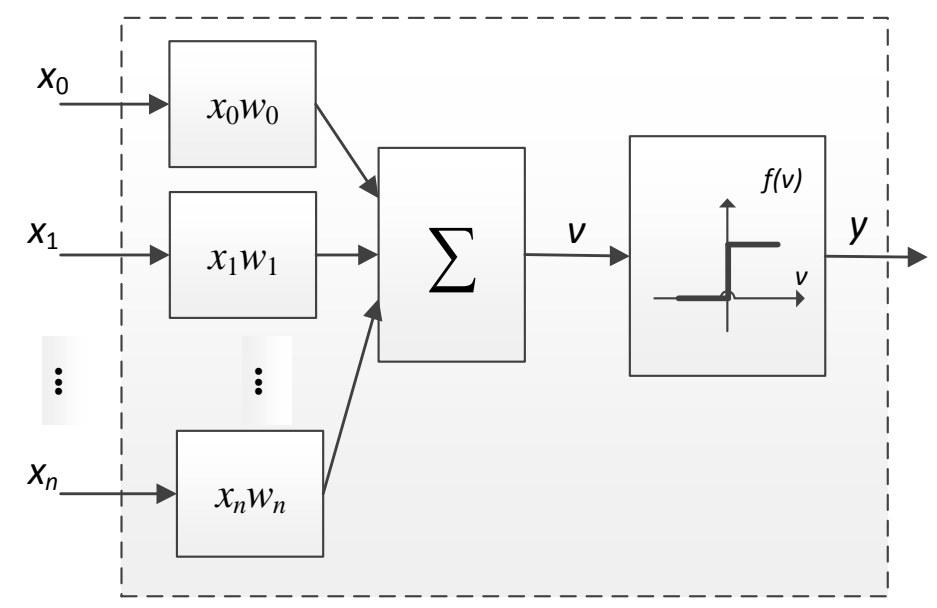

\section{Рис. 5. Модель нейрона}

Моделювання зв'язків між нейронами відбувається шляхом масштабування вхідних сигналів $\left(x_{0}, x_{1}, \ldots x_{n}\right)$ за допомогою вагових коефіцієнтів $\left(w_{0}, w_{1}, \ldots, \mathrm{w}_{n}\right)$. Одержані сигнали вводять на вхід суматора, який виконує їх оброблення за формулою:

$$
v=\sum_{i=0}^{n} w_{i} x_{i}
$$

Змінна $v \in$ аргументом порогової активаційної функції $y=f(v)$ найпростішим прикладом якої є функція:

$$
y=\left\{\begin{array}{l}
1 \text { при } v \leq a \\
0 \text { при } v>a
\end{array}\right.
$$

Узагальнена ієрархічна структура багатошарової нейронної мережі (рис.6) складається $3 m$ нейронів першого (прихованого) шару, які одночасно здатні прийняти вхідний вектор сигналів $\mathrm{X}=\left(x_{1}, \ldots, x_{i}, \ldots, x_{n}\right), \mathrm{i} k$ нейронів другого (вихідного) шару. Згідно 3 моделлю формального нейрона, кожен 3 його вхідних сигналів множать на ваговий коефіцієнт $w_{i j}$, де $i$ - поточний номер елемента вектора $\mathrm{X}$, а $j$ - поточний номер нейрона.

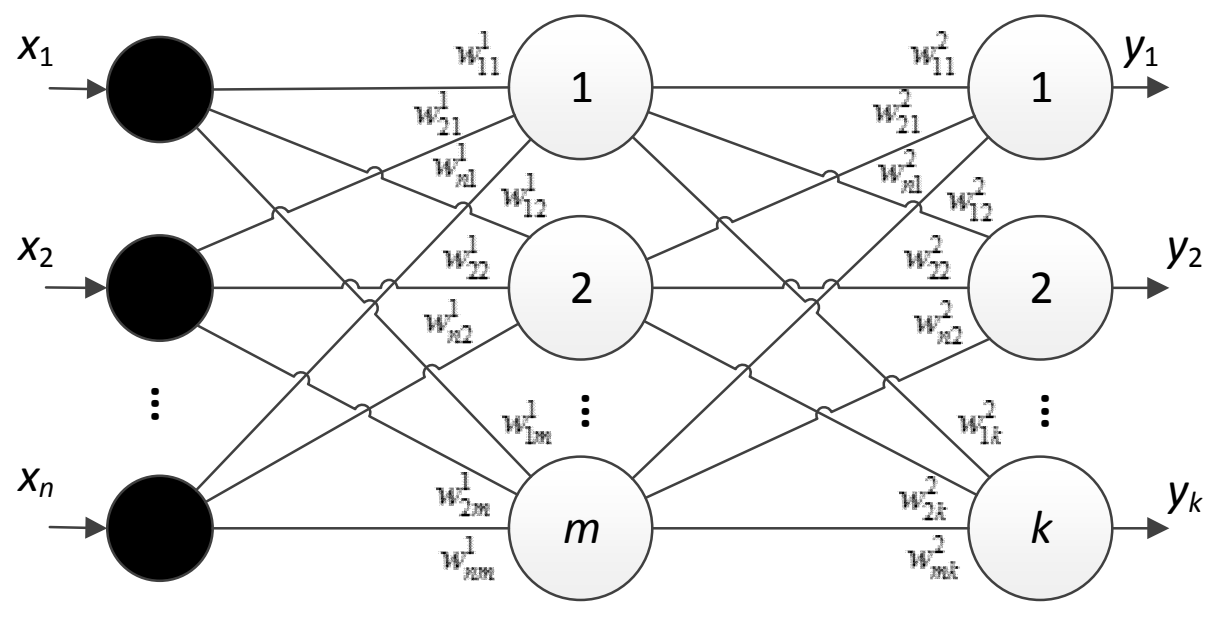

Рис. 6. Багатошарова нейронна мережа

Під час вибору конфігурації нейронної мережі фахівці [7; 9] наводять низку рекомендації частково емпіричних, завдяки яким можливо оцінити прийнятну кількість нейронів для розв'язання певного завдання: 
- кількість нейронів у вхідних і вихідних шарах жорстко визначається кількістю вхідних і вихідних змінних моделі відповідно;

- чим більш нелінійною є задача, тим більше має бути прихованих шарів (зазвичай обирається 1-3 прихованих шарів);

- кількість нейронів у прихованих шарах $\mathrm{i}$ кількість прихованих шарів обираються так, щоб кількість утворюваних ними зв'язків була меншою кількості навчальних прикладів щонайменше у два-три рази і приблизно обчислюють за формулою (висновок з теореми Арнольда - Колмогорова):

$$
\frac{N_{y} Q}{1+\log _{2}(\mathrm{Q})} \leq N_{w} \leq N_{y}\left(\frac{Q}{N_{x}}+1\right)\left(N_{x}+N_{y}+1\right)+N_{y}
$$

де $N_{y}$ - розмірність вихідного сигналу, $Q$ - число елементів множини навчаючих прикладів; $N_{w}$ - необхідна кількість зв'язків; $N_{x}$ - розмірність вхідного сигналу.

Обчисливши за цією формулою необхідну кількість зв'язків $N_{w}$, розраховуємо необхідну кількість нейронів у прихованих шарах. Для структури нейронної мережі 3 одним прихованим шаром кількість нейронів прихованого шару дорівнюватиме:

$$
N=\frac{N_{w}}{N_{x}+N_{y}},
$$

Після визначення конфігурації мережі необхідно виконати відповідне настроювання ваг зв'язків, тобто провести навчання нейронної мережі, щоб вона змогла виконувати очікуване оброблення даних.

Процес навчання нейронної мережі (рис. 7) передбачає настроювання вагових коефіцієнтів зв'язків так, щоб $з$ усіх можливих функцій $f \in F$ нейронна мережа виконувала функцію $f^{\prime}$, максимально близьку (min функції похибки $E$ ) до цільової функції $g$. Для навчання нейронної мережі цільова функція має бути завдана у вигляді таблиці навчальних прикладів парами значень «відомий вхід - відомий вихід».

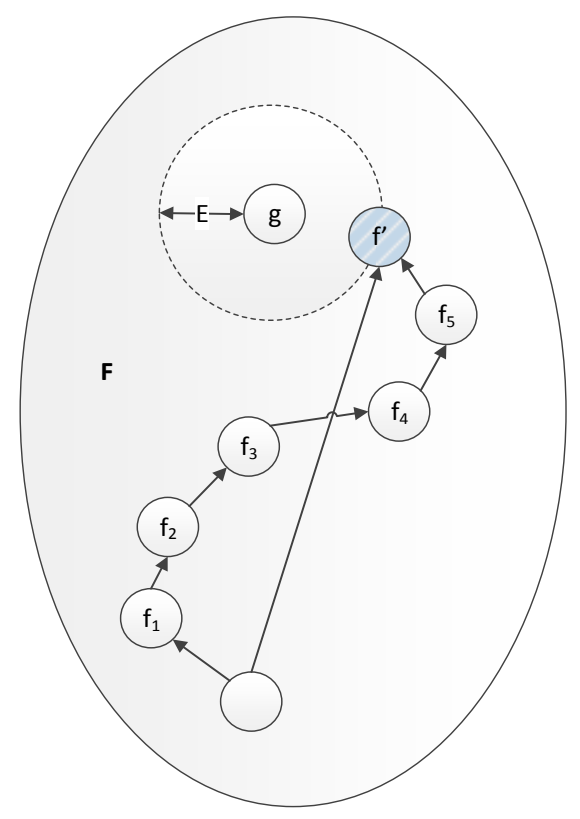

Рис. 7. Процес навчання нейронної мережі 
Важливим питанням під час проведення низки експериментів 3 нейронною мережею певної конфігурації $є$ процедура обрання кількості й умов проведення експериментів, необхідних і достатніх для розв'язання певного завдання з необхідною точністю. Застосування методів планування експерименту дозволяє визначити похибку моделі, яка представлена нейронною мережею, i зробити висновки щодо іiі адекватності [5].

Особливо складно проводити автоматизоване тестування 3 гуманітарних дисциплін, з іноземної мови зокрема. Відповіді на гуманітарні питання є нечіткими, неоднозначними порівняно з точними науками, також неможливо заздалегідь знати всі можливі відповіді. Тому метод групового експертного оцінювання залишається кращим у розв’язанні проблеми комплексного тестування з іноземної мови, коли екзаменатори виставляють бали за письмовий переклад з іноземної мови рідною, письмовий переклад 3 рідної мови іноземною, володіння лексичним матеріалом, володіння граматичним матеріалом, розуміння мови співрозмовника, розуміння фонограми на слух, уміння вести бесіду, змістовний бік мовлення. Зауважимо, що кожний вищезазначений вид мовленнєвої діяльності є окремим тестом.

У табл. 2 наведено приклади обчислюваної матриці роздрібнюваного експерименту для семи тестів (“+1" - верхній, “0” - середній, “-1” - нижній рівні варіювання параметру), які будуть використані у ролі навчальних елементів сумісно 3 інтегральною оцінкою в цій низці експериментів.

Таблиия 2

\section{План обчислюваного експерименту для сімох тестів}

\begin{tabular}{|c|c|c|c|c|c|c|c|c|}
\hline \multirow{2}{*}{$\begin{array}{c}\text { № } \\
\text { експерименту }\end{array}$} & \multicolumn{7}{|c|}{ Параметри } & \multicolumn{1}{c|}{ Результат } \\
\cline { 2 - 9 } & $\boldsymbol{T}_{\mathbf{1}}$ & $\boldsymbol{T}_{\mathbf{2}}$ & $\boldsymbol{T}_{\mathbf{3}}$ & $\boldsymbol{T}_{\mathbf{4}}$ & $\boldsymbol{T}_{\mathbf{5}}$ & $\boldsymbol{T}_{\mathbf{6}}$ & $\boldsymbol{T}_{\mathbf{7}}$ & $\boldsymbol{R}$ \\
\hline 1 & +1 & -1 & +1 & -1 & +1 & +1 & +1 & 0 \\
\hline 2 & +1 & +1 & -1 & -1 & +1 & +1 & +1 & +1 \\
\hline 3 & +1 & +1 & +1 & +1 & +1 & -1 & +1 & +1 \\
\hline 4 & -1 & +1 & +1 & -1 & +1 & -1 & +1 & -1 \\
\hline 5 & -1 & -1 & +1 & +1 & -1 & -1 & +1 & -1 \\
\hline 6 & +1 & +1 & +1 & -1 & +1 & +1 & -1 & +1 \\
\hline 7 & +1 & -1 & +1 & +1 & -1 & +1 & -1 & 0 \\
\hline$\ldots$ & $\ldots$ & $\ldots$ & $\ldots$ & $\ldots$ & $\ldots$ & $\ldots$ & $\ldots$ & $\ldots$ \\
\hline
\end{tabular}

Задля розв’язання вищезазначених завдань потрібні комплексні рішення в галузі інформаційно-аналітичних технологій, які можливо застосовувати у сфері освіти, сучасним представником яких є Deductor Studio Academic.

Дані для навчання мережі мають бути сформовані в текстовому файлі з розділювачами (Тab чи пробіл). Потрібно забезпечити, щоб дані були не суперечливими. Надалі налаштовуємо параметри імпорту файлу з даними навчання, зазначивши формат вхідного файлу, шлях до нього і місцезнаходження заголовка (рис. 8), та перевіряємо коректність зчитування полів програмою. 


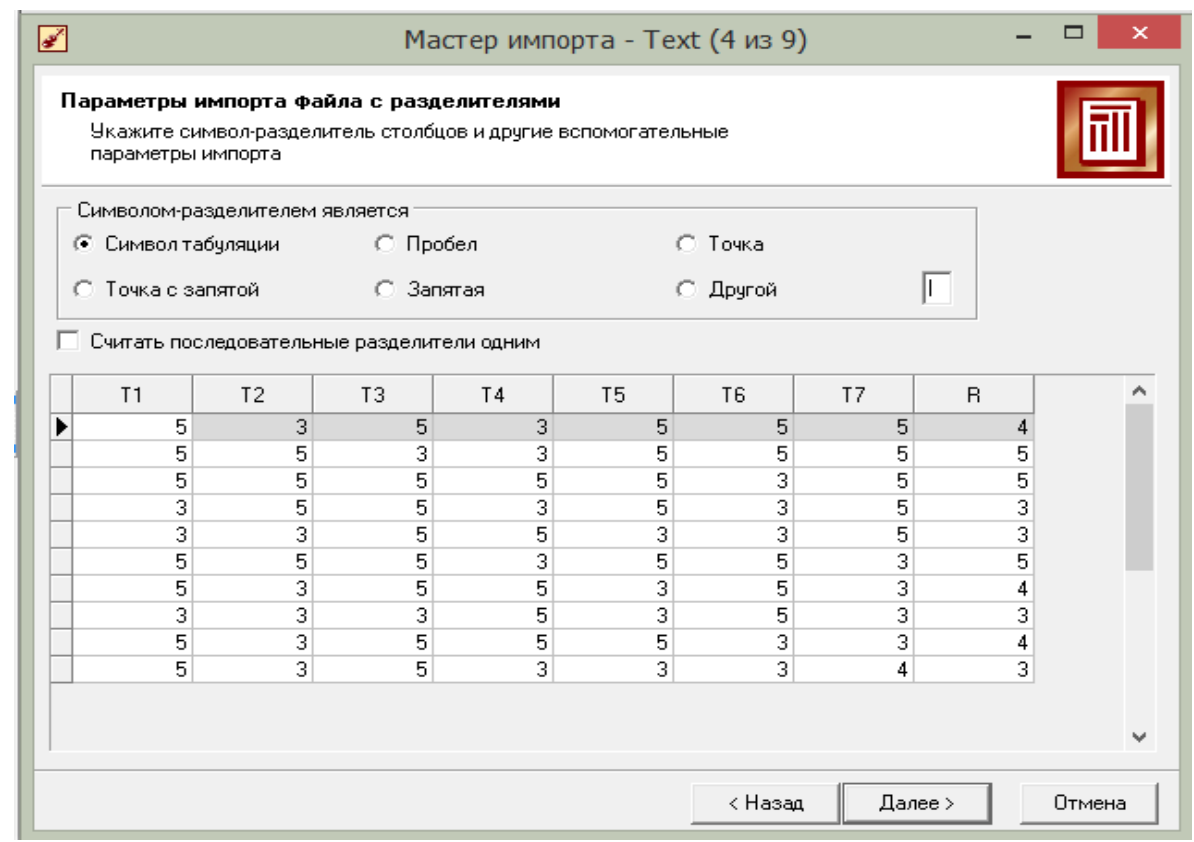

Рис. 8. Налаштування прочедури зчитування даних

Кількість нейронів у першому й останньому шарах залежить від того, які поля позначаються як вхідні й вихідні. Для нормалізації вхідної інформації можуть використовуватися такі методи: лінійна нормалізація, експонентна нормалізація, автонормалізація, що заснована на статистичних характеристиках вибірки, без нормалізації. (рис. 9).

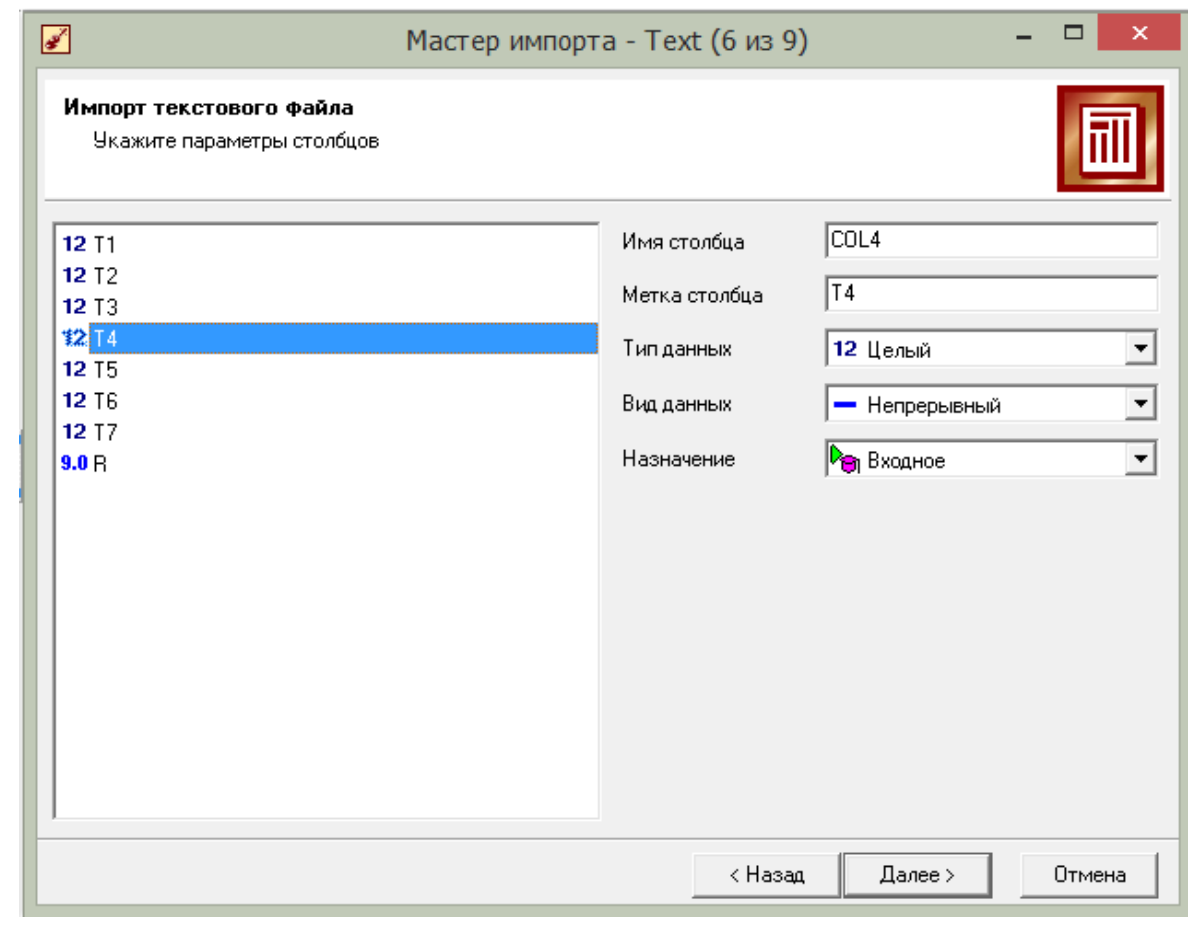

Рис. 9. Поле і його властивості

У аналітичному середовищі Deductor Studio Academic можуть бути реалізовані різноманітні варіанти статистичного оброблення даних, зокрема методами інтелектуального оброблення даних Data Mining, до складу яких входить нейромережа, (рис. 10), що дозволяє особам навіть без спеціальної математичної освіти проводити 
аналіз великих масивів даних (групові експертні оцінки) 3 їх обчисленням i візуалізацією результатів (інтегральні оцінки рівня сформованості ІКК слухача за результатами комплексного тестування).

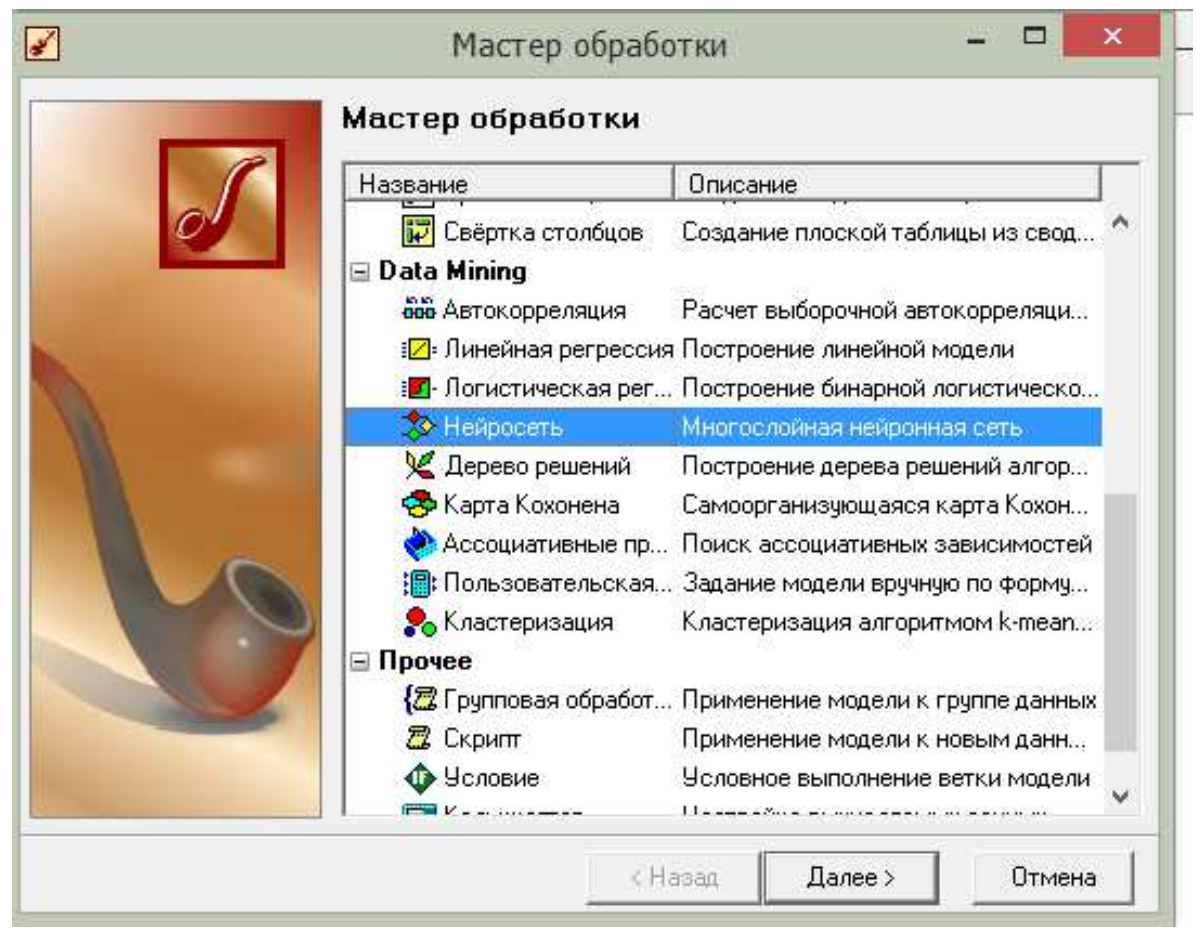

Рис. 10 . Створення нейронної мережі

Усі приклади, що вводять на вхід нейромережі, поділяються на дві множини навчальну і тестову (рис. 11). У програмі визначається, скільки відсотків прикладів буде використано в навчальній вибірці. Записи, що використовуються для тестування нейромережі, вибираються випадково, але пропорції зберігаються.

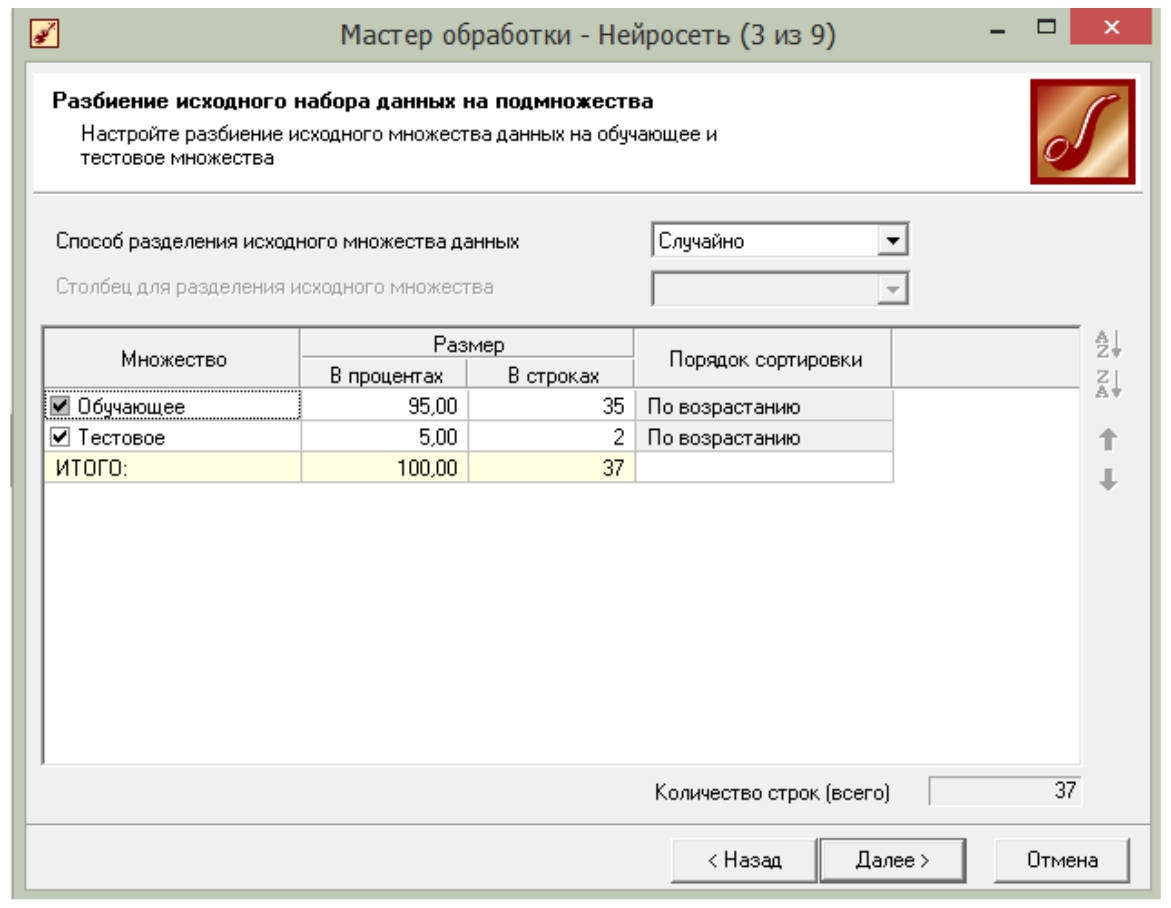

Рис. 11 . Визначення вибірок налаштування нейромережі 
Оскільки нейронна мережа обов'язково має вхідний і вихідний шари, то необхідно вказати кількість прихованих шарів (рис. 12). Сигмоїда застосовується для забезпечення нелінійного перетворення даних. Параметр сигмоїди підбирається емпірично.

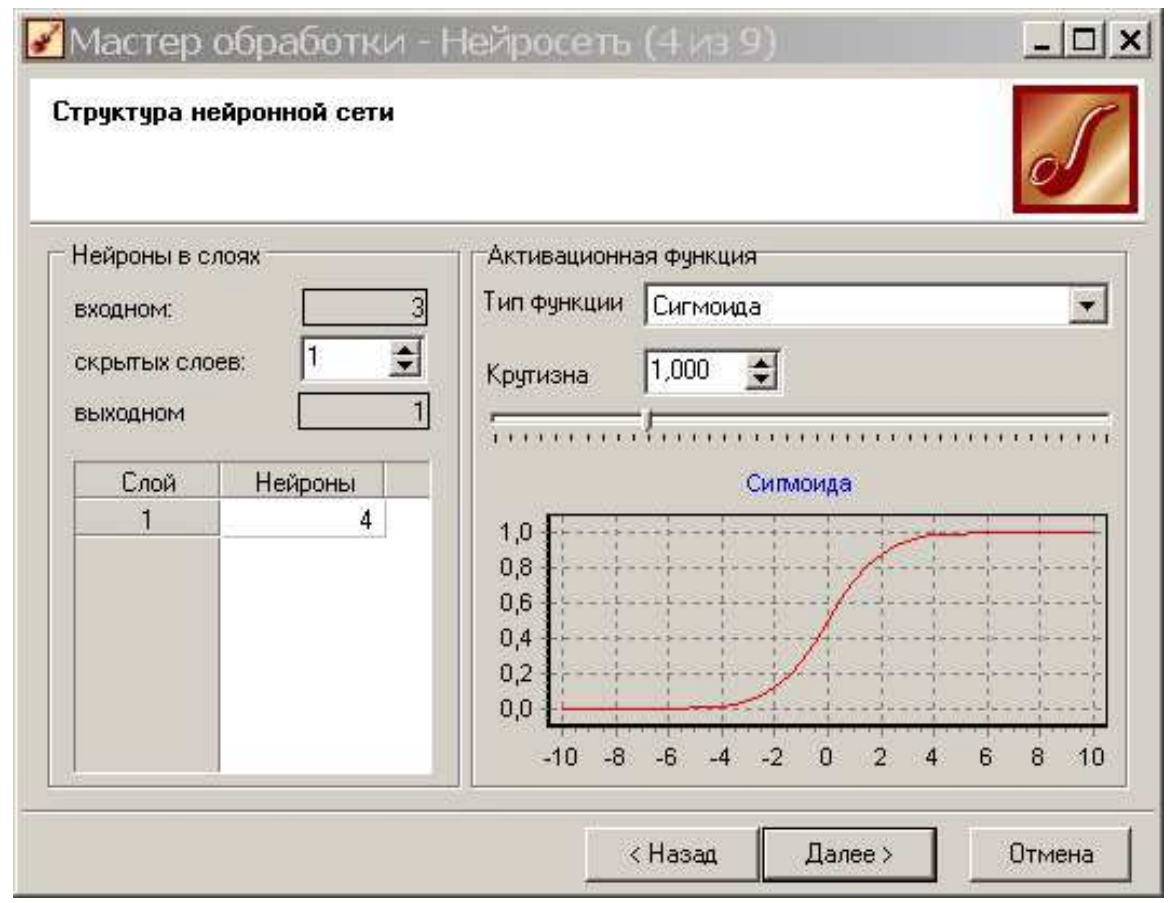

Рис. 12. Параметри нейромережі

Інтерфейс користувача програми дозволяє здійснювати вибір алгоритму i параметрів навчання (рис. 13), завдяки чому визначається послідовність аналізу вхідних даних і швидкість навчання.

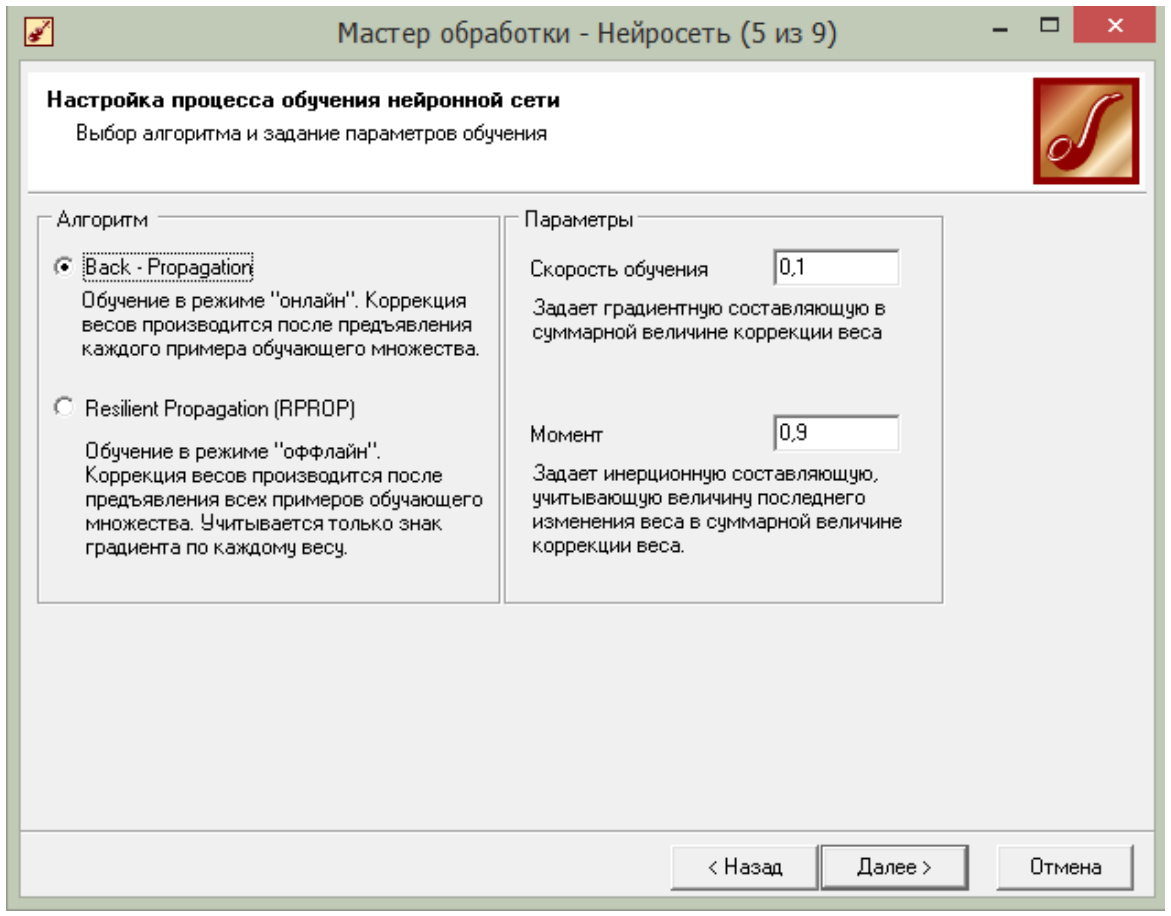

Рис. 13. Вибір алгоритму і параметрів навчання 
Важливим моментом у навчанні нейромережі $є$ визначення, коли навчання буде закінчено, тобто визначення критерію зупинення навчання (рис. 14). Якщо результат прогнозування відрізняється від значення з навчальної множини так, що є меншим за вказану величину, тоді приклад вважається розпізнаним.

\begin{tabular}{|c|c|c|c|}
\hline \multicolumn{3}{|c|}{ Мастер обработки - Нейросеть (6 из 9) } & $-\square x$ \\
\hline \multicolumn{4}{|l|}{ Настройка параметров остановки обучения } \\
\hline \multicolumn{4}{|l|}{$\begin{array}{l}\text { Укажите условия прекращения обучения. Обучение будет } \\
\text { остановлено при выполнении одного из условий. }\end{array}$} \\
\hline Считать пример распознанным, если ошибка меньше & 0,05 & & \\
\hline 『 По достижению эпохи & 1000 & $\Delta$ & \\
\hline [06учающее Множество - & & & \\
\hline Г Средняя ошибка меньше & $\Gamma$ & & \\
\hline Г Максимальная ошибка меньше & $\Gamma$ & & \\
\hline Г Распознано примеров [\%] & & 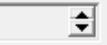 & \\
\hline \multicolumn{4}{|l|}{- Тестовое множество $^{-}$} \\
\hline \multicolumn{4}{|l|}{ Г Средняя ошибка меньше } \\
\hline \multicolumn{4}{|l|}{ Г Максимальная ошибка меньше } \\
\hline \multirow[t]{2}{*}{$Г$ Распознано примеров (\%) } & 0 & $\rightarrow$ & \\
\hline & $<$ Назад & Далее > & Отмена \\
\hline
\end{tabular}

Рис. 14. Параметри зупинення навчання

Розпочинаючи процес навчання нейронної мережі (рис. 15), можна спостерігати, як змінюється помилка навчання у навчальній/тестовій вибірці та інші важливі параметри, від яких залежить тривалість цього процесу.

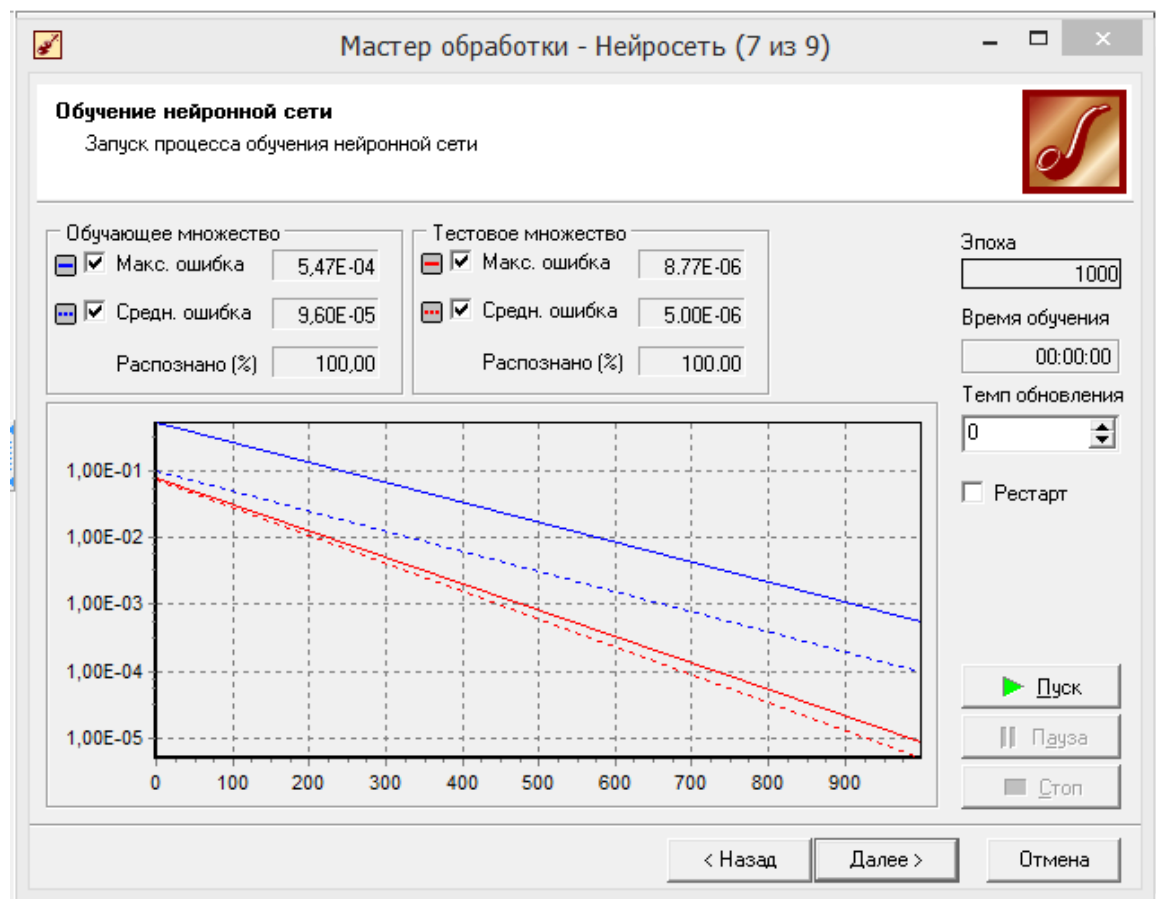

Рис. 15. Процес навчання 
На цих графіках розподілу прикладів у навчальній/тестовій вибірці можна відслідкувати, наскільки результати, що прогнозовані нейронною мережею, збігаються зі значеннями в навчальній (ліворуч) і тестовій (праворуч) вибірках. Необхідно прагнути, щоб точки розташовувалися якнайближче до діагоналі.

Методи інтелектуального аналізу даних супроводжуються значними можливостями щодо візуалізації отриманих результатів. Використаний програмний продукт дозволяє вибирати різноманітні способи відображення даних (рис. 16).

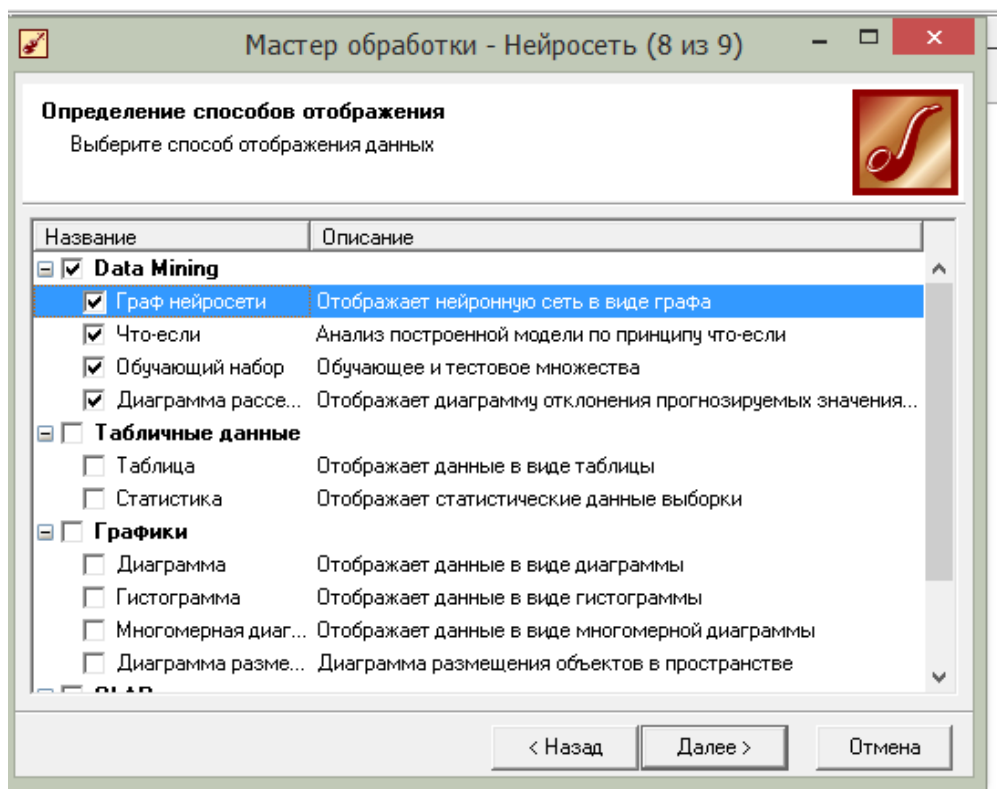

Рис. 16. Визначення способів відображення результатів

Структура штучної нейронної мережі, яка створена у цьому проекті, зображена у виді графа (рис. 17).

У діаграмі розсіяння відображається розподіл помилки прогнозованих значень (рис. 18). Чим правіше стовпець, тим вище значення помилки. Чим вищий стовпець, тим більше прикладів із зазначеною помилкою.

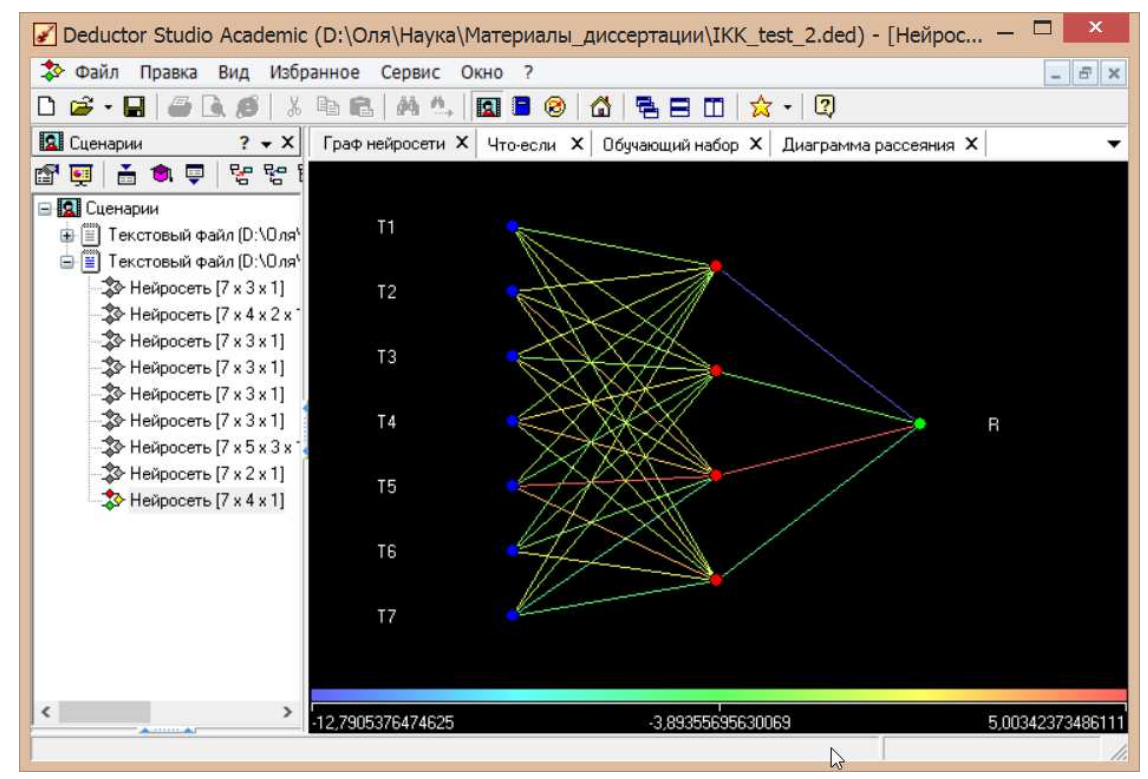

Рис. 17. Граф нейронної мережі 


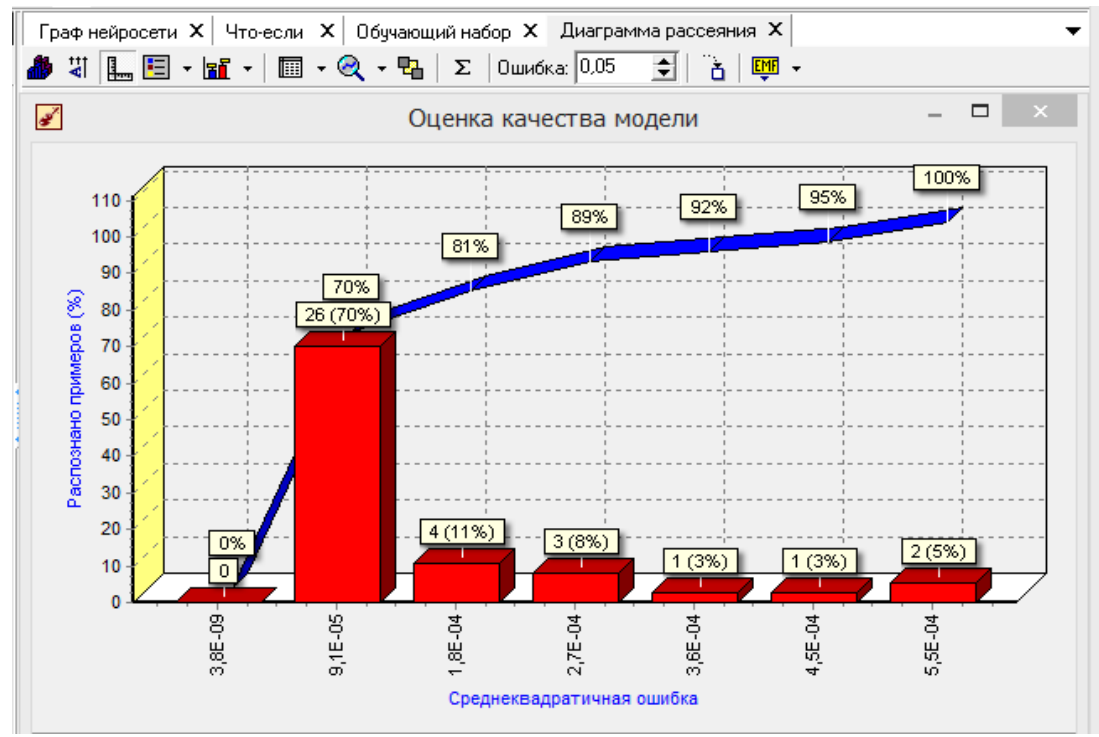

Рис. 18. Діаграма розсіяння помилки на навчальній вибіриі

Програмне середовище дозволяє проводити розрахунок кінцевого результату у режимі реального часу: у вкладці «що-якщо» набором вхідних параметрів слід увести числа, запустити модель у режим розрахунку й отримати результат (рис. 19).

Якщо результати перевірки моделі $є$ задовільними, то засобами програми зберігаються всі параметри і налаштування проекту у файлі. У подальшому успішний проект може бути використаний для обчислення інтегральних оцінок рівня сформованості ІКК слухачів за результатами комплексного тестування для значних масивів групових експертних оцінок (враховуючи кількість тестів, кількість членів екзаменаційних комісій та кількість слухачів). Наразі зазначена процедура носить максимально об'єктивний характер без задіяння висококваліфікованого ресурсу, використовуючи попередній досвід, який реалізований у моделі на основі штучної нейронної мережі.

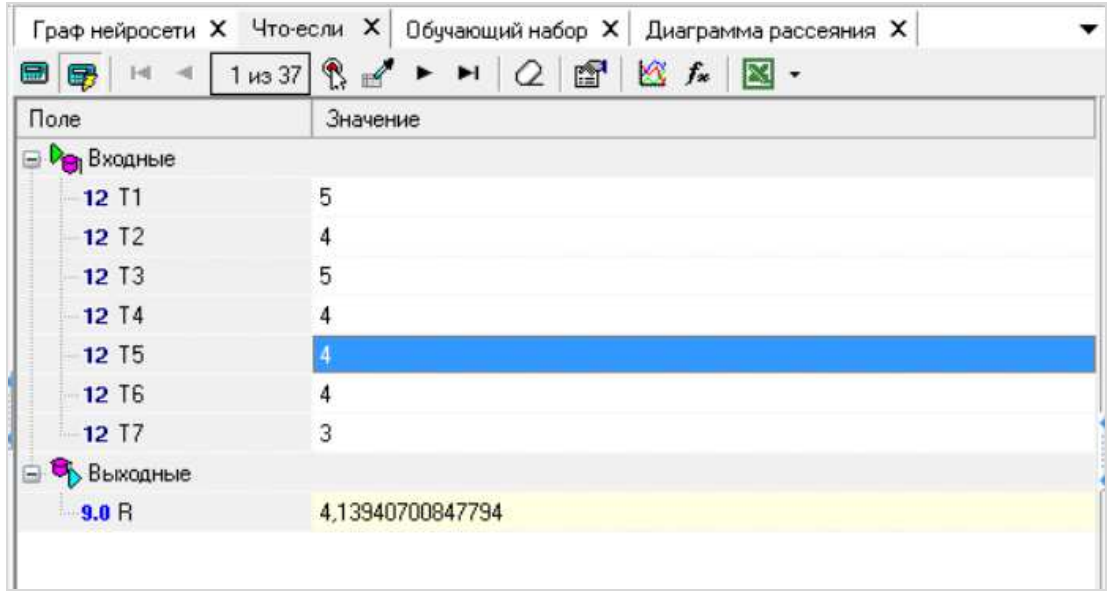

Рис. 19. Розрахунок кінцевих результатів

Отже, врахування впливу згаданих чинників обробки групових експертних оцінок за результатами комплексного тестування 3 іноземної мови може забезпечити отримання надійніших результатів оцінювання рівня сформованості ІКК слухачів. 


\section{3. ВИСНОВКИ ТА ПЕРСПЕКТИВИ ПОДАЛЬШИХ ДОСЛІДЖЕНЬ}

Проведені дослідження існуючих математично-статистичних методів розв'язання поставленого у статті завдання забезпечують обгрунтування запропонованого інтегрованого підходу оцінювання рівня сформованості ІКК слухачів, який органічно поєднує реалізацію двох шляхів оброблення інформації від експертів на базі сучасних спеціалізованих програмних рішень.

Математичні засади, що покладені в основу обчислення результатів тестувань 3 іноземної мови за сукупністю оцінок від групи експертів із застосуванням методу медіани Кемені за допомогою програмної надбудови AtteStat, значно підвищують їх об’ єктивність і дозволяють оцінити компетентність кожного з експертів й узгодженість групи у цілому.

Задіяння можливостей аналітичного середовища Deductor Studio Academic щодо обчислення інтегральної оцінки рівня сформованості IКК слухачів за результатами комплексного тестування, що реалізує моделювання нелінійного узагальнення на основі ШНМ, підвищують точність цього процесу і дозволяють у подальшому ефективно використовувати накопичений у моделі досвід компетентних експертів.

Незважаючи на те, що вже нині запропоноване рішення може бути інструментом удосконалення управління процесом навчання іноземних мов в ВНЗ України, щоб отримати якісний результат, треба розглянути питання вдосконалення методу медіани Кемені, питання ретельного підходу до підбору математичної моделі, покладеної в основу ШНМ, i питання розширення можливостей оброблення багатофакторних i багаторівневих статистичних вибірок для навчання, що вимагає подальших методологічних досліджень і практичної перевірки у визначеному напрямі.

\section{СПИСОК ВИКОРИСТАНИХ ДЖЕРЕЛ}

1. Бешелев С. Д. Математико-статистические методы экспертных оценок. / С. Д. Бешелев, Ф. Г. Гурвич. - М. : Статистика, 1980. - 263 с.

2. Гайдышев И. П. Программное обеспечение анализа данных AtteStat. Руководство пользователя. Версия 13. / И. П. Гайдышев. - 2012. - 506 с.

3. Компания BaseGroup ${ }^{\mathrm{TM}}$ Labs. Deductor. Руководство по алгоритмам. Версия 5.2.0 [Електронний pecypc] - 1995-2010. - Режим доступу : www.basegroup.ru

4. Лазарев В. М. Нейросети и нейрокомпьютеры. Монография. / В. М. Лазарев, А. П. Свиридов. - М., 2011. - $131 \mathrm{c}$.

5. Монтгомери Д. К. Планирование эксперимента и анализ данных. / Д. К. Монтгомери. - Л. : Судостроение, 1980. - 384 с.

6. Орлов А. И. Экспертные оценки : учеб. пос. / А. И. Орлов. - М. : Экзамен, 2002. - 31 с.

7. Паклин Н. Б. Биэнес аналитика: от данных к знаниям $(+\mathrm{CO})$ : учебное пособие. 2е изд., испр. / Н. Б. Паклин, В. И. Орешков. - СПб. : Питер, 2013. - 704 с.

8. Хабаров С. П. Экспертные системы [Електронний ресурс] / С. П. Хабаров. - Режим доступу : http://www.habarov.spb.ru/new_es/index.htm.

9. Ясницкий Л. Н. Введение в искусственный интеллект. Учеб. пособие для ВУЗов. / Л. Н. Ясницкий. - М. : Изд. центр «Академия», 2005. -176 с.

10. Hinton G. E. How neural networks learn from experience. [Електронний ресурс] / G. E. Hinton. Scientific American, September 1992. - Pp. 145-151. - Режим доступу http://www.cs.toronto.edu/ hinton/absps/sciam92.pdf.

11. Rojas R. Neural Network. / R. Rojas. - Berlin, Heidelberg Springer Verlag, 1996. - 502 p.

12. Wasserman P. D. Neural Computing. Theory and Practice. / P. D. Wasserman. - M. : Mиp, 1992. - 240 c.

Матеріал надійшов до редакиї 08.07.2015 p. 


\title{
ИНТЕГРИРОВАННЫЙ ПОДХОД К ОЦЕНИВАНИЮ УРОВНЯ СФОРМИРОВАННОСТИ ИНОЯЗЫЧНОЙ КОММУНИКАТИВНОЙ КОМПЕТЕНТНОСТИ С ПОМОЩЬЮ ИСКУССТВЕННЫХ НЕЙРОННЫХ СЕТЕЙ
}

\author{
Застело Ольга Вячеславовна \\ старший преподаватель кафедры иноязычной подготовки \\ ведомственный ВУЗ, г. Киев, Украина \\ girzov@ukr.net
}

\begin{abstract}
Аннотация. В статье рассматривается метод определения интегральной оценки уровня сформированности иноязычной коммуникативной компетентности слушателей группой экспертов в процессе комплексного тестирования по иностранному языку. Использование математических методов и современных специализированных программных средств при проведении комплексного тестирования слушателей, значительно совершенствуют экспертные методы, в частности в направлении повышения степени достоверности оценки. Задействование возможностей программной аналитической среды реализует моделирование нелинейного обобщения на основе искусственных нейронных сетей, что повышает точность оценки и позволяет в дальнейшем эффективно использовать накопленный в модели опыт компетентных экспертов.
\end{abstract}

Ключевые слова: экспертное оценивание; медиана Кемени; коэффициент конкордации; искусственная нейронная сеть.

\section{ARTIFICIAL NEURAL NETWORK BASED METHOD OF ASSESSMENT OF STUDENTS` FOREIGN LANGUAGE COMPETENCE BY THE GROUP OF EXPERTS}

\section{Olha V. Zastelo}

senior lecturer of foreign language training departmental university, Kyiv, Ukraine girzov@ukr.net

\begin{abstract}
In this article the method of the integral assessment of the level of students foreign language communicative competence by the group of experts through the complex test in a foreign language is considered. The use of mathematical methods and modern specialized software during complex testing of students significantly improves the expert methods, particularly in the direction of increasing the reliability of the assessment. Capitalizing analytical software environment realizes the simulation of non-linear generalizations based on artificial neural networks, which increases the accuracy of the estimate and allows further efficient use of the competent experts experience gained in the model.
\end{abstract}

Keywords: expert evaluation; Median Kemeny; coefficient of concordance; artificial neural network.

\section{REFERENCES (TRANSLATED AND TRANSLITERATED)}

1. Beshelev S. D. Mathematical and statistical methods of expert estimates. / S. D. Beshelev, F. G. Gurvich. - M. : Statistika, 1980. - 263 s. (in Russian).

2. Gaydyshev I. P. AtteStat: the software data analysis. User guide. Release 13. / I. P. Gaydyshev. - 2012. 506 s. (in Russian).

3. BaseGroup ${ }^{\mathrm{TM}}$ Labs. Deductor. Guide to algorithms. Release 5.2.0 [online] -1995-2010. - Available from: www.basegroup.ru (in Russian).

4. Lazarev V. M. Neural networks and neurocomputers. Monograph. / V. M. Lazarev, A. P. Sviridov. - M. : 2011. - 131 s. (in Russian). 
5. Montgomeri D. K. Experimental Design and Analysis. / D. K. Montgomeri. - L. : Sudostroenie, 1980. 384 s. (in Russian).

6. Orlov A. I. Expert assessment: Tutorial / A. I. Orlov. - M. : Ekzamen, 2002. - 31 s. (in Russian).

7. Paklin N. B., Oreshkov V. I. Business Analysis: from data to knowledge: Textbook. 2nd edition, Revised. / N. B. Paklin, V. I. Oreshkov.- SPb. : Piter, 2013. - 704 s. (in Russian).

8. Khabarov S. P. Expert systems [online] / S. P. Khabarov. - Available from: http://www.habarov.spb.ru/new_es/index.htm (in Russian).

9. Yasnitskiy L. N. Introduction to Artificial Intelligence. Textbook for Higher Schools./ L. N. Yasnitskiy. M. : Izd. tsentr «Akademiya», 2005. -176 s. (in Russian).

10. Hinton G. E. How neural networks learn from experience. [online] / G. E. Hinton. Scientific American, September 1992. - pp. 145-151. Available from: http://www.cs.toronto.edu/ hinton/absps/sciam92.pdf (in English).

11. Rojas R. Neural Network. / R. Rojas. - Berlin Heidelberg Springer Verlag, 1996. - 502 p. (in English).

12. Wasserman P. D. Neural Computing. Theory and Practice. / P. D. Wasserman. - M. : Mir, 1992. - $240 \mathrm{~s}$. (in English). 